\title{
Competing In The Global Environment: What Does Business Want From Economics
}

\author{
Michael E. Burns, (E-mail: michael.burns@unisa.edu.au), University of South Australia
}

\begin{abstract}
Despite globalization and the associated increased need for understanding of the real and financial processes at work in the global economy, since the 1950's there has been an ongoing significant and worldwide fall in the number and quality of undergraduates studying for an economics degree. Surprisingly, responses by the economics profession have included very little serious consideration of the factors underlying the actual and potential demand by business for their product. This paper explores and identifies the fundamental characteristics of the real world environment in which business activity takes place and which shape the kinds of decisions that are important to business. It is seen that the content and presentation of current economics curricula bear little relation to this environment even though economic analysis and insight have significant potential to make international business decision-making more profitable. Directions for the development of business economics curricula are suggested.
\end{abstract}

\section{Introduction}

A selection of conference papers published in the Summer 2001 volume of The Journal of Economic Education draw attention to the declining demand for economics as well as to the response of the economics profession to this decline. Despite globalization and the associated increased need for understanding of the real and financial processes at work in the global economy, since the 1950's there has been an ongoing significant and worldwide fall in the number and quality of undergraduates studying for an economics degree. This has been accompanied by an almost equally dramatic increase in the demand for undergraduate business degrees. Many of the students enrolled in first year economics classes have a primary interest in business but they elect to study little or no more economics beyond first year. Commonly cited reasons for negative attitudes towards economics are its abstract nature and lack of relevance, especially to business decision-making. Surprisingly, responses by the economics profession have included very little serious consideration of the factors underlying the actual and potential demand by business for their product.

Expressed in its simplest form, what business wants from economics is clearly 'anything that assists business to make more profitable decisions'. A more detailed answer would need to be based upon consideration of the actual types of decision seen as important by business, taking into account the key real world characteristics of the environment in which business activity takes place. There are several reasons why economists should be interested in such a more detailed answer.

First, many of the students enrolled in first year economics classes have a primary interest in business. Second, partly by choice and partly at the direction of professional bodies, many of these students elect to study little or no more economics beyond first year. Third, commonly cited reasons for negative attitudes towards economics are its abstract nature and lack of relevance, especially to business decision-making. Finally, if these criticisms have any substance, a re-focusing of economics towards business reality can only increase the attractiveness of economics to students and business employers. It must also better equip those aiming to become professional economists, whether their interests lie in policy analysis, areas such as industrial economics, productivity and regulation or even economic modeling.

Readers with comments or questions are encouraged to contact the author via email. 
This paper is organized as follows. First, the recent trends in enrolment in economics are reviewed, as are the responses by the economics profession. It is seen that these responses have given negligible attention to any examination of demand for the profession's products. Insights into actual and potential demand are then developed initially through an examination of the major characteristics of the business environment. Drawing on these characteristics, business perceptions as to an appropriate decision-making or strategy process are identified. Key elements of this framework relating to the nature of business organizations, the purchase process and the importance of differences between individuals are discussed in more detail. Throughout, relevant economic analysis and insights are identified and the paper closes with a short consideration of how economics teaching has been and might be influenced by the perspective presented.

\section{Falling Demand and the Response by the Economics Profession}

Since the 1950's globalization and the associated increase in international business activity have made understanding both real and financial aspects of international trading environment central to business decision making. The processes driving these changes in the global business environment have also led to an increasingly competitive marketplace, heightening the importance of understanding of the competitive process. While these changes might have been expected to result in an increase in the demand for economic insights, the opposite appears to have been the case. The Scholarship of Teaching Economics conference held at the University of Melbourne in July 2000 highlighted both the recent trends in enrollments in economics courses and the broad flavor of the response by the economics profession.

As noted by Siegfried and Round (2001), the interest of American undergraduates in studying for an economics degree has dropped precipitously three times since World War II. These authors also note that the trends in absolute numbers of economics degree completions over the last decade in Australia, Canada, Germany and the United States have been remarkably similar. Their focus on absolute numbers, of course, grossly understates the fall in market share that would be apparent when the increases in population and in the demand for related business degrees are taken into account.

The responses of the economics profession, the broad flavor of which is captured by the mix of papers presented at this conference and reflected in those selected for publication in the conference volume, would appear curious to many business practitioners. Johnston, McDonald and Williams (2001) suggest in their introduction to the conference volume that the thrust of research into economics education can be grouped into three broad categories: who should determine the curriculum; what should be taught; and, how should it be taught. While these categories might appear to offer scope for identifying an appropriate response to market place changes within the climate of precipitously declining demand, the reality is different.

Johnston et al see the papers presented at the conference as raising the important question as to whether considering the needs of potential employers and the views of students on content and delivery might positively influence demand. While their views are clearly in sympathy with those of Burns (2000), they clearly do not see much current research as having meaningfully addressed this issue. Thus, when the question of "what should be taught' is considered by Gartner (2001), the concern is not whether the content of economics serve the market, but whether there is sufficient uniformity of content worldwide to enable students of economics to talk to each other in a common language. As Johnson et al succinctly state, 'uniformity is not a virtue if people wear the wrong uniform'.

Much of research into economic education has focussed upon how economics should be taught, represented in the conference volume by Shanahan and Meyer (2001) who address what Johnston et al refer to as the "emerging recognition that a focus on how students learn and how we teach is important'. These are important questions, but less so if the insights are applied to the continued production of products that are not valued in the marketplace.

The issue here is straightforward and familiar to all students of marketing. In the seminal contributions by Philip Kotler to marketing and to business practice in general, the fundamental message is that successful business activity must be driven by the matching of an organisation's capabilities to what is valued in the marketplace. Business organizations have not always done this and texts such as Kotler, Ang, Leong and Tan (1996) usefully identify 
three historically common but inappropriate approaches to the marketplace. They term these three orientations the Production Concept, the Product Concept, and the Selling Concept and elements of each of these underlie the broad approach of the economics profession to the marketplace. These orientations are to be compared with the preferred Marketing Concept, an approach which derives from the view that organizational success in the marketplace is about identifying what target markets value and delivering this more efficiently and effectively than competitors.

The Production Concept holds that consumers will favor low cost products that are widely available. The costs of studying economics are not only the direct financial costs but include entry standards and the degree of difficulty in completing a degree program. Efforts to improve the efficiency and effectiveness of supplying the existing product range, whether based upon improved understanding about how students learn, upon the use of new technologies or simply upon increased class size, clearly fall within the Production Concept category. While no one would suggest that the economics profession has favored this approach above all others it is appears to be true that elements of this approach have been adopted.

The Product Concept draws on the view that consumers will favor high quality products with innovative features, but where the innovation occurs within the existing product range. There is no doubt that within the economics profession there are those who hold views as to the superiority (more rigorous nature) of what they do compared to other business practitioners. It is also true that much of the innovation that is valued within the profession has been in research that rigorously extends understanding within the existing product framework. In neither case has the question of what is valued (or thought superior) in the marketplace been a major consideration. Similarly, elements of the Selling Concept, which focuses on the need for aggressive selling and promotion efforts, can be found in the efforts of those who seek to restore demand by promoting their own perceived values of the existing range of economists' products while taking no account of contrary perceptions held in the marketplace.

There is a strong case to be made that the declining demand for undergraduate economics derives from its perceived irrelevance to the general competitive business environment. The rest of this paper explores how relevance can be increased. The approach unashamedly reflects a Marketing Concept orientation and takes as a starting point the quotation introduction Kotler et al's chapter on analyzing consumer markets and buyer behavior. We are advised that 'to be a bullfighter you must first learn to be a bull' and so it is that if economists are to take on business they must learn what it is to be an entrepreneur. While macroeconomics and an understanding of the real and financial processes at work in the international economy clearly contribute importantly to international business considerations, the focus here will largely be with analyzing the competitive environment and the microeconomic business decision-making which is relevant to this environment, both in domestic and international business activity.

\section{How should we judge what Business wants from Economics?}

There is more than one way an economist without business training can obtain insights into what business might want from economics. An obvious approach would be to ask business directly, but for a number of reasons that is not what is suggested here. First, such an approach would be costly in terms of both time and other resources. Second, bearing in mind that it is the role of business schools and related organizations to develop, and inform business of, better ways to make business decisions, these schools themselves are likely to be a better source of insight into our question. It is this source of insight that guides our considerations here and an informal approach can be quite but effective. The websites of the business schools worldwide are readily accessible and from these sources, overall approaches to graduate business education can be identified, as well as some of the most commonly referred to texts whenever reading lists for the key functional areas were provided.

A number of texts identified in this and other ways have proved particularly valuable in the development of the present paper. In the management and strategy areas these have included: Porter (1980,1985,1990), Kay (1994), Oster (1994), Davis and Devinney (1997), Quinn, Mintzberg and James (1988), Mintzberg (1994), and Robey (1991). In the marketing area at least one of Philip Kotler's contributions to marketing management should be required reading for all economics students and teachers, the choice here being Kotler et al (1996). In the broad area of business economics useful sources include Williamson (1988), Earle (1995), Milgrom and Roberts (1992), Brickley, Smith and Zimmerman (1997), Besanko, Dranove and Shanley (1996), Fitzroy, Acs and Gerlowski (1998), 
Ehrenberg and Smith (1988) and Lazear (1998). Kay, in particular, and Earle are outstanding in their coverage of, and insights into key contributions to the business and management literatures.

What is clear from these sources is a high degree of consensus as to the nature of the environment in which business takes place and the increasing importance attached to the competitive strategy process. There is broad agreement as to which are the seminal contributions to the analysis of business behavior within this environment. There also appears to be a growing consensus as which types of decision business perceives to be important as well as to the which factors appear to be associated with the success of some businesses compared with others.

\section{The Competitive Business Environment}

Arguably the most insightful description of the competitive environment within which business strategies must be played out is that provided over fifty years ago by Schumpeter. At that time, that author welcomed the increasing willingness of economists to accommodate features such as product differentiation, quality competition and sales effort into their analyses of market behavior. He argued then, however, that the standard treatment of competitive forces and dynamics still took place within the rigid framework of constant technologies, population, tastes and industrial organization. Largely the adjustments that took place were towards static long-run equilibrium while the receipt of normal profits was the stable state to which almost all firms tended and would be content to remain. Much current teaching of first year and intermediate level economics would offer a very similar view of the competitive environment to that which Schumpeter criticized so eloquently:

"But in capitalist reality as distinguished from its textbook picture, it is not that kind of competition that counts but the competition for the new commodity, the new technology, the new source of supply, the new types of organizations..." (Schumpeter, p.84)

Importantly, associated with this view of competitive action is an accompanying competitive state of mind without which business success cannot be sustained:

"It is hardly necessary to point out that competition of the type we now have in mind acts not only when it is in being but also when it is merely an ever-present threat. It disciplines before it attacks. The businessman feels himself to be in a competitive situation even if he is alone in his field..." (Schumpeter, p.85)

Of all the popular economists' models of firm behavior, a dynamic version of monopolistic competition is the one that fits most usefully in Schumpeter's framework. The dynamic element is fundamental because the gains from new commodity design or from new and more efficient production methods are not simply competed back to 'a normal rate of return'. In general a product will sooner or later be made obsolete, either by the innovations of competitors or those of the producer of that commodity. This notion of a product life-cycle is central to business thinking and a typical profile is shown in Figure 1.

Here for expositional purposes, discounted dollars of economic profit per period (based upon revenues and costs from the time of the first sale) are measured on the vertical axis. Normal profit would be achieved over the product life cycle if the areas bounded by the curve above the zero economic profit line exceeded the area bounded below by an amount equal to or greater than the costs incurred ( $e g$ on research and development) prior to the first sale. Within the context of the product life cycle the rent-seeking activities of business organizations assume more urgent purpose than simply being an objective of entrepreneurial activity. What is clear is that to achieve normal or greater profits over the life of a product a significant period of market domination is required. A period of time in which economic rents can be obtained is essential if the costs of research and development are to be offset and a (risk adjusted) normal rate of return earned over the complete life cycle.

Figure 1: Economic Profits Over The Product Life Cycle, From Time Of First Sale 


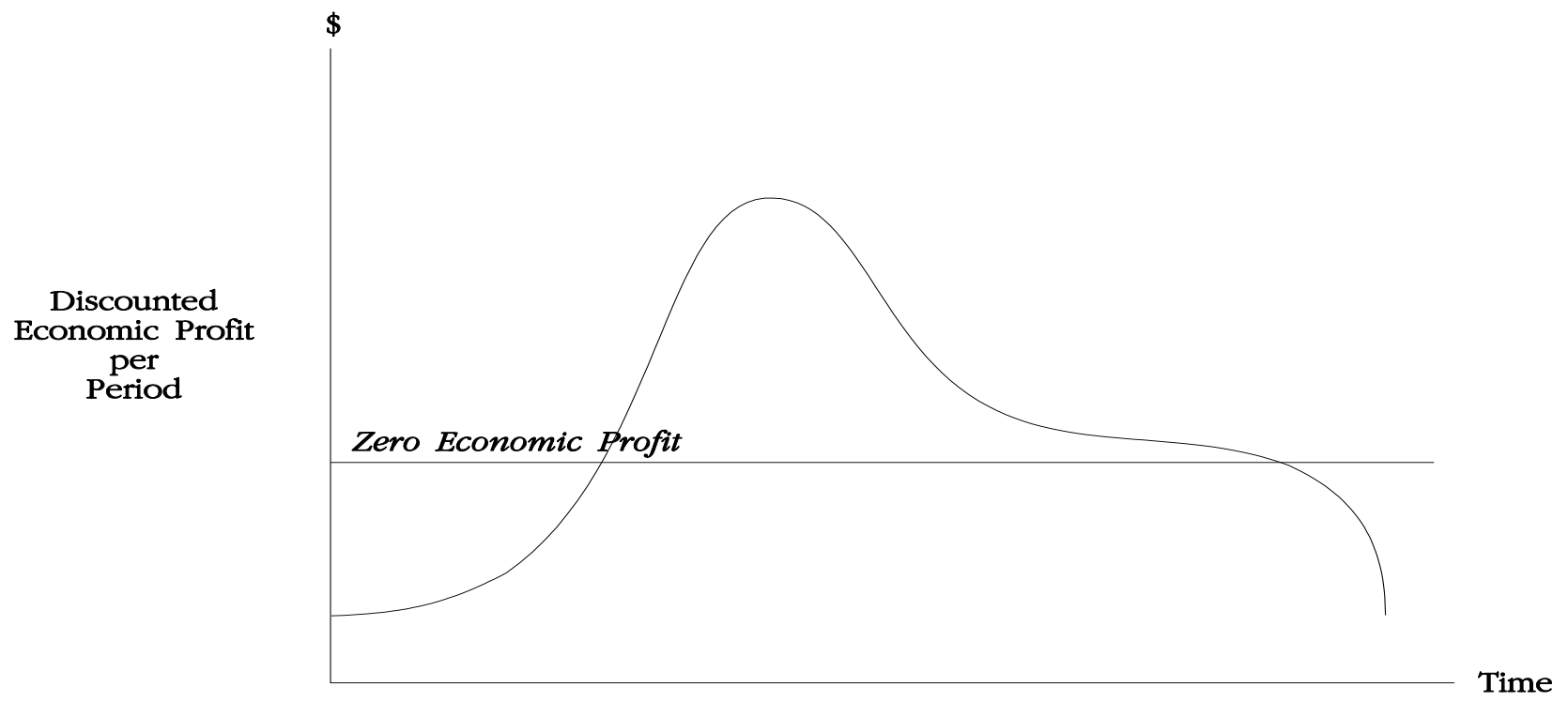

These views of the competitive environment, of the most representative type of firm and the challenges facing such a firm were substantially neglected until the more recent contributions of Porter. Here, the dependency of business success on the creation of competitive advantage "... by perceiving new and better ways to compete in an industry and bringing them to market. (Porter 1990, p. 45)", fits firmly within Schumpeter's competitive paradigm.

There are a number of characteristics of such a business environment that are fundamental with regard to identifying the type of economic analysis likely to be most useful to business. First, both consumers and suppliers care about today and the future with the consequence that many of the interesting aspects of business decisionmaking are concealed in single-period optimizing approaches. Second, the business environment is dynamic with population, skills, technologies, and tastes adjusting continuously, in markets that have always exhibited unpredictable elements and where transaction costs preclude instantaneous adjustment. Third, for the reasons identified and because information is costly, almost all market decision-making is made under uncertainty. To these general characteristics we may add others arising from more detailed empirical considerations. On this basis a fourth fundamental characteristic is, in general, that decision-makers prefer less uncertainty and therefore are prepared to pay to reduce it. Fifth, and equally fundamental to the activities we observe taking place within the business environment, is that individuals differ in their tastes, skill levels and attributes as well as in their incomes and wealth. It is this characteristic that drives the product differentiation we observe in almost all markets. Finally, further empirical characteristics that impact upon production choices are the economies of scale and of scope that appear to underlie many production processes.

All of this helps to identify the kinds of economic analysis and insight that might add value to business organizations. What is not clear so far, however, is how we might bring together the roles of basic economic ideas and the clearly more advanced analyses suggested by our considerations of the nature of the business environment in which individuals and organizations interact. A useful way to proceed is to place our considerations within the modern competitive strategy framework found, in one form or another, in most graduate and undergraduate business programs.

\section{The Need to be Different and/or Better}

While the business notion of success as achieving maximum expected profit or shareholder wealth subject to the constraints imposed by the business environment fits well with economic analysis, the approach of business as to how to achieve this success goes far beyond simplistic consideration of marginal optimization conditions. Since 
its origins in Schumpeter and its development through writers such as Porter and Kay, competitive strategy has had as a central theme the need for organizations to identify ways in which they are able to be different and/or better in some fundamental respect if they are to outperform their competitors. Nowhere has this been put more succinctly than perhaps by Oster, who in the introduction to her recent text makes the point:

\section{"If everyone can do it, you can't make money at it (Oster, p.13)."}

While this simple statement admirably captures the competitive state of mind regarded as fundamental to those who wish to 'play the business game' it is perhaps misleading in its simplicity. There is clearly a converse perspective equally fundamental to business survival and success, that:

"If a business does not make use of commonly understand techniques and methods of business practice, then that business is likely to go bankrupt".

There are of course a range of basic concepts and techniques in economics, finance and accounting which fall within this category and these would include but go beyond the useful lists of basic concepts suggested by Chrystal and Lipsey (1997) and by Mankiw (1998). Clearly they would also range in complexity from the notions of opportunity cost and market forces, to the question of interaction between markets as well as to the more complex ideas associated with portfolio analysis and the marginal rules for optimal resource allocation. These thoughts here are also helpful in answering the logical query of more curious students, as to whether there is any point in teaching business analysis since once taught the information is available to all and cannot be a source of rents. A satisfactory answer might note both the costs of failure to understand basic and widely known business methods, and that understanding of newer and more complex business methodology is currently a scarce resource.

\section{How Businesses Maximize: the Structure of Strategy.}

The need to be different and or better permeates all business activities and is a fundamental part of the structure of strategy, illustrated in Figure 2 below. This structure replaces simplistic notions about businesses maximizing their chances of success purely by satisfying a number of marginal conditions and provides a useful framework to see what is that firms actually do if their aim is to maximize current and discounted expected future profits. Each stage of the process offers a role to suitable economic analysis and insight, including a place for the familiar notions of optimization and opportunity cost, but it is understanding the overall process that is the key. Later we shall examine three key components of this structure in greater depth, but first, a brief overview of the process is provided.

\section{Distinctive Capabilities: Ways in which Organizations may differ.}

As in simple SWOT analysis the starting point of the strategy process involves an assessment of the firms internal environment and of its strengths and weaknesses. It is possible, however, to give these terms sharp and meaningful definition. Weaknesses can be related to the failure to use 'best' commonly available business methods in the sense discussed above. Similarly, strengths may be related to the capacity to do one more things better than, or differently, to ones competitors. Various writers in the strategy area have found it useful to offer a simple categorization of the ways in which businesses might seek to obtain some advantage over their competitors through doing 'something' differently or better.

Kay suggests looking among four distinctive capabilities, whereby firms can produce goods and services more efficiently and/or exploit market situations more effectively than their competitors in the dynamic business environment. These capabilities, identified in Figure 2, relate to organization, strategic assets, innovation, and reputation. In each case, a clear role for economic insight and analysis is easily seen. The first of these, sometimes referred to as organizational architecture, is concerned with the relationships that exist between individuals within and across organizations. As an area this comprises almost the entire focus of fields such as Human Resource Management and Organizational Behavior. Because of its importance to business decision-making and also because of the potential relevance of economic analysis and insights, it will be examined in more detail below. 
Detailed discussions of some of the sometimes interrelated roles of strategic assets, innovation and reputation can be found in Kay, Porter (1990), Davis and Devinney, and in Burns (1996), as well as in many modern industrial organization texts. These discussions embrace: natural monopoly; economies of scale; sunk costs (in all their forms); experience curves; and, strategic entry considerations. The matter of reputation, which in part relates to innovation and early-moving, is importantly connected to the question of how individuals and businesses respond to uncertainty in a world with transaction costs, a recurring theme in business decision-making.

\section{Finding an Appropriate Market}

A distinctive capability may not be valued in the market place. At least for private organizations, the identification of actual or potential capabilities must therefore be followed by the identification of a market where an appropriate rate of return is likely to be obtained over the lifetime of the product. This step, in the manner of Porter's 'five forces' analysis, considers not only demand characteristics but also the likely responses of other participants in a particular market and the possibility that initial rents may be appropriated by other stakeholders in the market. It may be related to the 'opportunities and threats' of SWOT analysis, noting with Kay that such analysis is not 'strategy' but only a 'framework for thinking'.

\begin{tabular}{|c|}
\hline $\begin{array}{c}\text { Understanding The Nature Of The Business Environment } \\
\text { Organizational Objectives and Constraints } \\
\text { Dynamic monopolistic competition }\end{array}$ \\
\hline $\begin{array}{l}\mathbf{V} \\
\mathbf{V}\end{array}$ \\
\hline $\begin{array}{l}\text { Identifying Actual And Potential Distinctive Capabilities } \\
\text { Organizational Architecture } \\
\text { Innovation } \\
\text { Reputation } \\
\text { Strategic Assets }\end{array}$ \\
\hline $\begin{array}{l}\mathbf{V} \\
\mathbf{V}\end{array}$ \\
\hline $\begin{array}{c}\text { Identifying A Market Where Capabilities Are Valuable } \\
\text { Product Demand } \\
\text { Market Analysis and Appropriability }\end{array}$ \\
\hline $\begin{array}{l}\mathbf{V} \\
\mathbf{V}\end{array}$ \\
\hline $\begin{array}{c}\text { Maximizing the value of competitive advantage } \\
\text { Positioning and Pricing } \\
\text { Advertising and Branding }\end{array}$ \\
\hline $\begin{array}{l}\mathbf{V} \\
\mathbf{V}\end{array}$ \\
\hline $\begin{array}{c}\text { Defending And Sustaining The Value Of Competitive Advantage } \\
\text { Vertical relationships }\end{array}$ \\
\hline
\end{tabular}

Source: Based upon Kay (1994).

Figure 2: The Structure Of Strategy

Maximizing the Value of Competitive Advantage 
In a world where differences among individuals lead to product differentiation and where organizations have some flexibility as to the precise use of their distinctive capabilities, simply identifying a market with an adequate return is clearly sub-optimal. Searching across attribute space for the most profitable product location based upon both attribute valuation and product costs is a key business activity. While the most recent marketing literature on segmentation and positioning, such as McDonald and Dunbar (1995), fails to successfully integrate value considerations into the perceptual mapping framework or into what is termed needs-gap analysis, economic analysis has much to offer in this area.

\section{Defending and Sustaining the Value of Competitive Advantage}

It is in the nature of competition that an organization's capacity to earn economic rents will attract attention both from outside and within the organization. Each of the parties to agreements with an organization (identified in Figure 3 below), as well as competitors, will seek to compete away as much of these rents as market forces permit. A variety of tactics that have been adopted to delay the inevitable process of rent depletion have been widely discussed in the economics literature. Mergers have been one form of defense and while horizontal integration is usually prohibited under anti-monopoly regulation, vertical integration is generally a legitimate form of protection against the actions of suppliers. Other methods of defending and sustaining competitive advantage have been, where possible, through the use of sunk costs, through patents or through being able to set an industry standard, through franchising and, associated with the above or independently, through achieving reputation. What is important here is that it is a natural element of the strategy process to consider defense and sustainability, and to consider all possible means of delaying the entrance of competitors to markets that are temporarily dominated. It is also clear that the extent to which an organization believes it will be able to defend and sustain any competitive advantage that it is likely to gain will effect its investment in product development.

\section{Major Areas of Business Decision-Making}

As compared to standard economic textbook treatments, there are three major areas of the strategy process where business decision-making draws on far more detailed consideration of market behaviour. In each of these areas there is an abundance of existing economic analysis and insight that could undoubtedly enhance business decision-making.

\section{Distinctive Organizational Capabilities}

A firm's organizational architecture has been seen as a key area where significant improvements are possible and where major gains in competitive advantage can be made. In a recent textbook developing this view, Brickley, Smith, and Zimmerman define organizational architecture as encompassing three important aspects of organisation:

- $\quad$ The assignment of decision-rights (rights to decide and take actions) among individuals;

- $\quad$ The payment/reward system; and

- The performance evaluation system.

The first of these involves the dimensions of job design such as the bundling of tasks into jobs as well as the level of empowerment while the second addresses directly the range of financial agreements into which firms must enter. The second and third aspects most clearly offer roles for economic analysis to aid business decisionmaking. The importance of these organizational features has long been recognized, as evident in Coase (1937), more recently in Williamson and in the numerous contributions of Jensen and Meckling. It is central to the analysis of corporate success by Kay and to recent texts such as those of Milgrom and Roberts (1992) and Lazear as well as in the management literature, Robey (1991). It is also increasingly being recognized in first year economics texts, as in Lipsey and Chrystal and in McTaggart, Findlay and Parkin (1992).

Central to appreciation of business decision-making in general, and to the importance of organisational ar- 
chitecture in particular, is an expanded view of what defines a firm. Fitzroy, Acs and Gerlowski (1998) makes this the starting point of their recent text on organizational economics. Two approaches are helpful here: Jensen and Meckling's (1976) view of the firm as '..a legal fiction that serves as a nexus of contracts' (illustrated in Figure 3); and, the view of the business organization that derives from Porter's Chain of Value concept, shown in Figure 4.

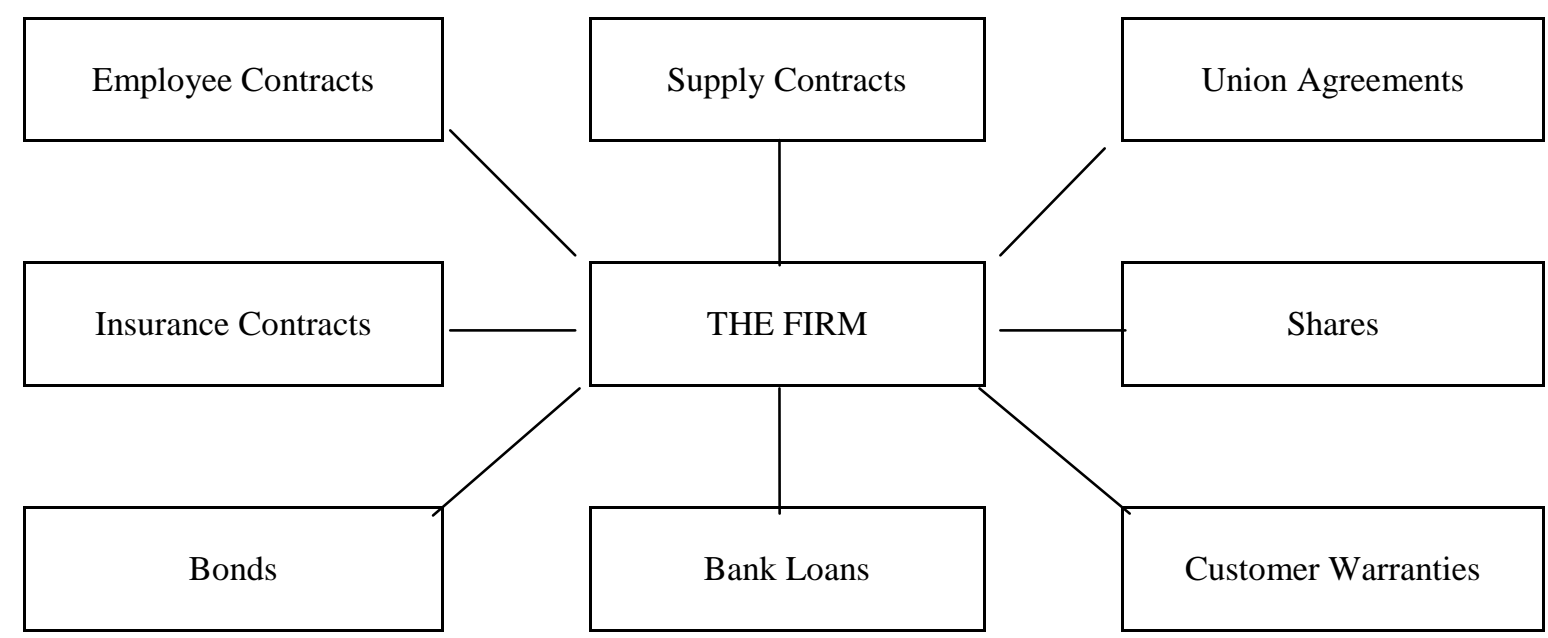

Figure 3: The Firm As A Nexus Of Contracts

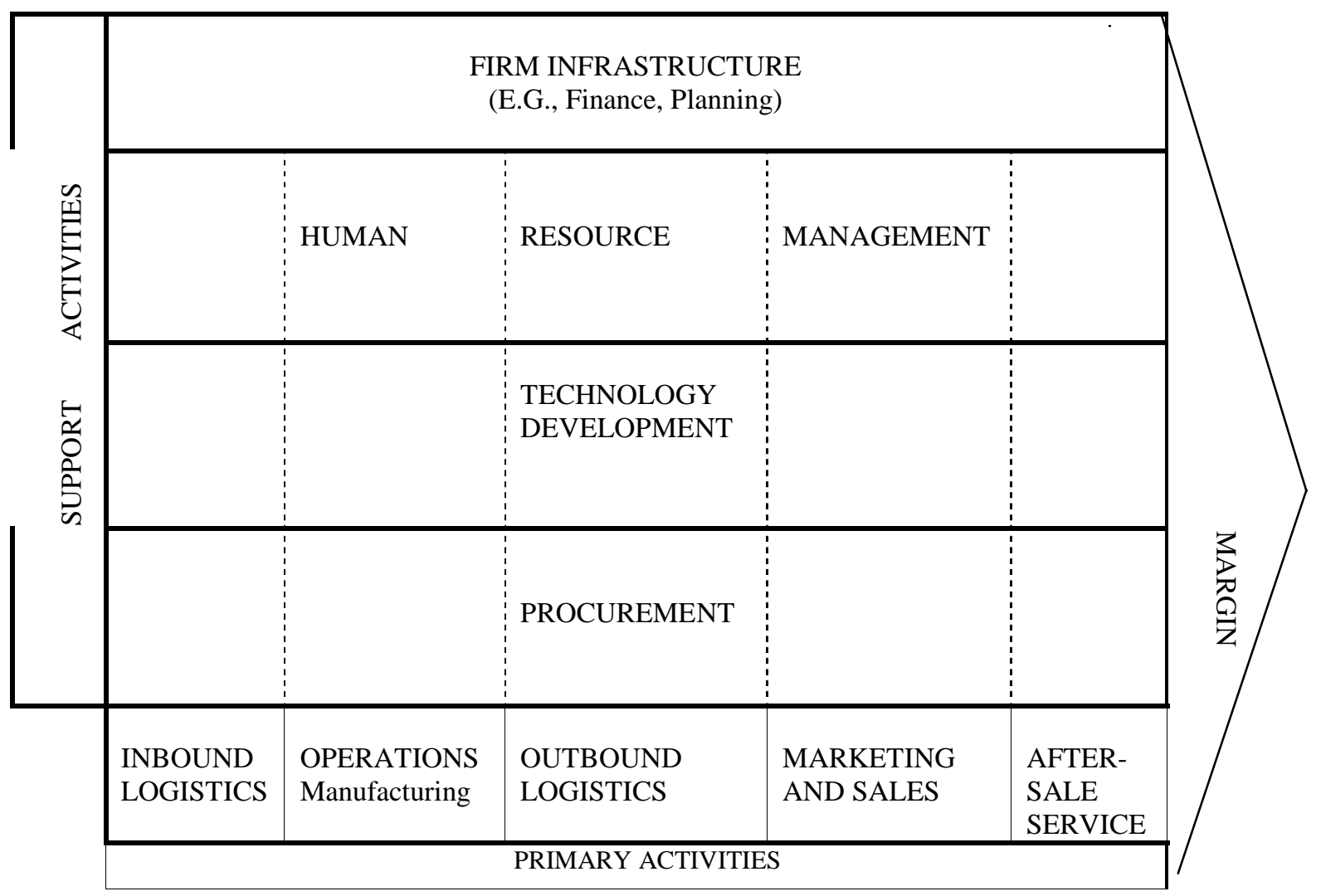

Figure 4: The Value Chain 
To see the importance of these expanded views of what defines a business, note that:

- A firm's contracts and relations include those internal to the organization, external contracts involving purchase or sale of goods and services, and informal external networks (as in Michael Porter's 'clusters');

- $\quad$ Contracts and/or relationships must exist between each of a firm's primary activity centres (inbound logistics, operations, outbound logistics, marketing and sales, after sales service) and their support activity centres (firm infrastructure, human resource management, technology development, procurement);

- In each relationship conflicting objectives, incomplete information and transaction costs generate coordination problems.

Each relationship therefore represents a 'profit opportunity' to organizations skilled in reducing these conflicts and agency problems. There is a significant literature addressing how economic analysis can assist business in addressing the principal-agent issue and other informational problems, as well as in developing optimal incentive contracts. Useful analsyses and summaries of some of the key issues, however, can be found in Milgrom and Roberts, Lazear and in Brickley, Smith and Zimmerman. Of course, the greater uncertainty inherent in relationship that function across national borders, together with the greater associated transactions and monitoring costs, heighten the importance of organizational skills in multinational corporations.

\section{The Purchase Process}

Understanding of the factors that influence purchase decisions is central to business decision-making and a focus of the marketing literature. With the exception of technical treatments, such as in Lilien et al (1992), marketers tend to make only limited explicit use of economic analysis. However, it is quite evident from any major marketing text, such as Kotler et al, that economic analysis has the potential to be a source of insight into all aspects of the purchase process.

The importance of the purchase process is perhaps most easily seen in the context of the purchase of durable goods, although the principles are applicable to almost all purchase decisions. It is worth noting, however, that in developed economies by far the larger part of household expenditures relates to durable goods. We can therefore immediately confirm the importance of intertemporal decision-making and of the concepts of permanent income, wealth, and intertemporal prices.

More important than the simple intertemporal aspect in itself, however, is the issue of buyer uncertainty and transaction costs. The sources of uncertainty as to what is actually being purchased are many, including technological change, untried and new products, future prices and asset values as well as natural variability in product quality. Bearing in mind the almost universal willingness of purchasers to pay for reduced uncertainty, important observable aspects of purchase behavior and supplier responses to this behavior become readily explicable. Economic insights into behavior towards uncertainly that follow from expected utility theory and prospect analysis, from portfolio analysis and from risk-pooling approaches towards warranties and insurance are immediately seen to be valuable.

The practice of buyer search for price and product information raises the issue of value of time. Here again economics insights have a clear role to play, whether time is valued through an opportunity cost approach or through Becker's (1965) model embodying 'full prices' and time costs of consumption. The latter model, of course, usefully suggests the broad effects of real wage increases on relative 'full' prices and on patterns of consumption and purchase behavior. Within this framework, and bearing in mind that skills will need to be learned to extract services effectively from many products purchased, the approach of Kotler et al to the purchase decision makes perfect sense. It also provides a basis for a range of common business decisions.

Purchases are viewed as being based upon the concept of delivered value, which takes into account the full range of sources of value and cost to (potential) purchasers. These include pre- and post- purchase behavior by businesses which reduce perceived uncertainty, which add value to the purchase (e.g. training), and even those which make the actual purchase experience less stressful and/or more enjoyable. They also include the time, material, and psychic costs incurred by purchasers in addition to any money price paid to the seller. 


\section{The Importance of Differences between Consumers}

If one major focus of marketing activity is exploiting understanding of the purchase process then the second major focus is exploiting understanding of the difference between individual purchasers. In the language of Kotler et al we are talking here about the whole process of segmentation, targeting and positioning (STP), a process that embraces what economists might term optimal vertical and horizontal differentiation.

Business has paid particular attention to segmentation and to the characteristics that might be usefully associated with differences in buying patterns, such as income, household composition, location, gender, age, and culture. The underlying motivation is straightforward and relates to the standardization v. adaptation choice where the savings from economies of scale have to be traded off against the premium individuals are willing to pay for products that more closely meet their preference orderings over attributes. A further relevant consideration is that the focused promotion made possible through segmentation is far more cost-effective than specific product promotion to entire populations. It goes without saying that just as organizational skills are even more relevant within the increasingly globalized business environment, so are the skills associated with STP.

There are many economics tools and insights that can potentially add value to the STP process. They range from the introductory treatments of price discrimination to more complex analysis of horizontal and vertical differentiation as well as the associated optimal pricing literature. The characteristics analysis associated with Lancaster $(1966,1979)$ offers a useful framework for consideration of horizontal differentiation, as does the empirical hedonic approach due to Rosen (1974). Mussa and Rosen (1978) developed a framework for analysis of vertical (quality) differentiation while Lipsey and Eaton (1989) provide an excellent survey of the economic literature on differentiation to that date. Phlips (1983) offered a comprehensive treatment of the associated areas of price discrimination and differentiation, while Nagel and Holden (1995) provide one of the few texts entirely concerned with pricing strategy. More recently, Burns (2000) developed the earlier Burns and Walsh (1981) demand distribution analysis to derive optimal differentiation and segmentation rules for both monopolistic and monopolistically competitive markets containing many heterogenous consumers.

\section{Concluding Comments: Applying Business Perspectives to Teaching Economics}

The central theme of this paper has been that the continuing failure of economics in the marketplace lies in the professions' unwillingness to 'practice what they preach' and to attempt to match their undoubted distinctive capabilities with what is valued in the marketplace. Attention here has been focused upon how business perceives the environment in which its activities take place, and upon what are perceived to be the key decisions to be made to maximize it chances of success. This approach identifies clearly a range of economic analyses and insights that could enhance business decision-making of the type that actually takes place. The tools span a range of complexity ranging from introductory to upper undergraduate levels and for these to be covered at any level would clearly require an intermediate level micro-based business economics subject in addition to a principles course. Arguably, a complete coverage of the areas identified would need to go further and include additional upper level specialist material.

While the paper itself offers superficial insights it also contains a message that if economists are to take on the business market then they will each have to get inside the 'business mind' and this cannot be based upon a simple overview such as offered here. In this regard, hopefully a number of the texts referred to here will help others just as they have assisted the author. A recommended starting point would be for interested economists with no specific business backgrounds to go out and read parts of Schumpeter together with one of the Kotler marketing management texts such as that cited above. As indicated earlier in the paper, the author would make the latter compulsory reading for any undergraduate economist, both because it brings to the fore an enormous range of real word marketplace problems and because it does in such a way as to make transparent the potential contribution that economists insights can make to business decision-making.

No attempt has been made here to specify suggested contents for any particular economics subject. It is 
suggested, however, that knowledge of the range of tools that are useful for business is a valuable if not essential input into the design of principles and specialist courses. It should be emphasized, however, that shaping the contents of economics courses so as to match better what is valued in the marketplace does not mean that that some of the more interesting, complex and difficult analysis must be discarded, or that 'standards' must be lowered.

Some anecdotal evidence is available. The author has been involved in the development of international business degree programs since 1993, as well as in the development and teaching of economics courses that would fit the needs of such programs, bearing in mind the perspective discussed in this paper. In one of these degrees, intermediate microeconomics (in some form) and macroeconomics were specified as part of the compulsory core. Students were able to choose first, whether they took a traditional or business-focused intermediate microeconomics course and second, based upon their experiences, elective upper level courses in the areas of competitive strategy and economics of marketing.

Over a five-year period students chose the business options by a maintained majority of about 4:1, despite approximate equivalence of levels of difficulty. Arguably the 'business perspective' approach merits further exploration, and appropriate tests should be devised to determine what, if any, significant benefits might be expected from adopting such an approach. It would be surprising, however, if adjusting the way that economics is presented to undergraduate students in the manner suggested in this paper did not have positive effects. To put this a slightly different way, surely it would be expected that a country's (Ecoland's) efforts to export its products to another country (Bizland) are more likely to be successful if based upon understanding of the other country's (Bizland's) culture and business environment as well as upon knowledge of what products are actually demanded there.

\section{References}

1. Besanko, David, Dranove, David Shanley, Mark (1996), Economics of Strategy, Wiley: New York.

2. Brickley, J.A., Smith, C.W. and J.L. Zimmerman (1997), Managerial Economics and Organizational Architecture, Irwin: Burr Ridge, Ill.

3. Burns, M.E. (1996), "Business Strategy in the Competitive Environment: Lessons for Economic Policy Management", Economics of Business and Government Conference, Griffith University, Brisbane).

4. (2000), "Product Differentiation, Segmentation and competition", paper presented at the CEA Conference, June 2000, University of British Columbia, Vancouver.

5. (2000), "What does Business want from Economics", paper presented at The Scholarship of Teaching Economics conference, July 2000, University of Melbourne, Melbourne.

6. Burns, M.E. and C. Walsh (1981). "Market Provision of Excludable Public Goods: A General Analysis", Journal of Political Economy, 89, pp.166-91

7. Chrystal, K.A. and R.G. Lipsey (1997), Economics for Business and Management, Oxford University Press: Oxford

8. $\quad$ Coase, R.H. (1937), "The Nature of the Firm", Economica, 4, pp. 386-405.

9. Davis, J. and, T. Devinney, (1997), The Essence of Corporate Strategy, Allen and Unwin: St Leonards.

10. DeBoer, D.R. (1998), "The Business-Plan Approach to Introductory Microeconomics", Journal of Economic Education, 29, pp. 54-64

11. Dixit, A.K. and B.J. Nalebuff (1991), Thinking Strategically, Norton: New York

12. Earle, Peter E (1995), Microeconomics for Business and Marketing, Edward Elgar: Aldershot.

13. Eaton, B.C. and R.G. Lipsey (1989). "Product Differentiation", in Schmalinsee, R. and R.D. Willig, Eds. Handbook of Industrial Organisation, Volume 1; Elsevier Publishers: B.V.

14. Ehrenberg, R.G. and R.S. Smith (1988), Modern Labour Economics, Scott Foreman: Illinois.

15. Fitzroy, F.R., Acs, Z.J. and D.A. Gerlowski (1998), Management and Economics of Organisation - Pearson Education, (Financial Times-Prentice-Hall): Harlow.

16. Gartner, M. (2001), "Teaching Economics to Undergraduates in Europe: Volume, Structure and Contents", The Journal of Economic Education, 32, pp. 219-230.

17. Jensen, M.C. and W.H. Meckling (1976), "The Theory of the Firm, Managerial Behaviour, Agency Costs and Ownership Structure", Journal of Financial Economics, 3, pp. 305-60.

18. Johnston, C., McDonald, I and R.Williams (2001), "The Scholarship of Teaching Economics", The Journal of Economic Education, 32, pp. 195-201. 
19. Kay, J. (1995), and Foundations of Corporate Success, Oxford University Press: Oxford.

20. Kotler, Phillip, Ang Swee Hoon, Leong Siew Meng and Tan Chin Tiong (1996), Marketing Management: An Asian Perspective, Prentice Hall: Singapore.

21. Lancaster, K.J. (1966). "A New Approach to Consumer Theory", Journal of Political Economy, 74, pp. 13257.

22. Lancaster, K.J. (1979). Variety, Equity and Efficiency, Columbia University Press: New York.

23. Lazear, E. P. (1998), Personnel Economics for Managers, Wiley, New York.

24. Lilien, Gary, Kotler, Philip and K Sridhar Moorthy (1992), Marketing Models, Prentice-Hall: Englewood Cliffs

25. Lipsey, R.G. and A. Chrystal (1995), An Introduction to Positive Economics, Oxford University Press: Oxford.

26. Mankiw, N G. (1998), Principles of Economics, Dryden: Fort Worth.

27. McDonald, M. and I. Dunbar (1995), Market Segmentation, Macmillan: London.

28. McTaggart, D., Finlay, C. and J.M. Parkin (1992), Economics, Addison-Wesley: Sydney.

29. Milgrom, P.R. and J. Roberts (1992), The Economics of Organization and Management, Prentice Hall: Englewood Cliffs.

30. Mintzberg, H. (1994), The Rise and Fall of Strategic Planning, Prentice Hall: London.

31. Mussa, M. and S. Rosen (1978), “Monopoly and Product Quality”, Journal of Economic Theory, 18, pp. 301317.

32. Nagle, T.T. and R.K. Holden (1995), The Strategy and Tactics of Pricing, Prentice-Hall: Englewood Cliffs.

33. Oster, S.M. (1994), Modern Competitive Strategy, Oxford: New York.

34. Phlips, L. (1983), The Economics of Price Discrimination, Cambridge: Cambridge University Press.

35. Porter, M.E. (1980), Competitive Strategy: Techniques for Analysing Industries and Competitors, The Free Press: New York.

36. (1985), Competitive Advantage: Creating and Sustaining Superior Performance, The Free Press: New York.

37. (1990), The Competitive Advantage of Nations, Macmillan: London.

38. Quinn, J.B., Mintzberg, H., and R.M. James (1988), The Strategy Process, Prentice-Hall: Englewood Cliffs.

39. Robey, D. (1991), Designing Organizations, Irwin: Burr Ridge, Ill.

40. Rosen, S. (1974). "Hedonic Prices and Implicit Markets: Product Differentiation in Pure Competition", Journal of Political Economy, 82:34-55.

41. Shanahan, M.P. and J.H.F.Meyer (2001), “A Student Learning Inventory to Economics Based on the Students” Experience of Learning: A Preliminary Study”, The Journal of Economic Education, 32, pp. 259-268.

42. Siegfried, J.J. and D.K. Round (2001), "International trends in Economics Degrees During the 1990s", The Journal of Economic Education, 32, pp. 203-218.

43. Schumpeter, J.A. (1942), Capitalism, Socialism and Democracy, Harper and Row: New York.

44. Williamson, O.E. (1986), Economic Organization, Wheatsheaf: Hemel Hempstead. 
Notes 